\title{
Health Law Education with the Islamic Transcendental Paradigm: Efforts to Overcome the Loss of BPJS Kesehatan
}

\author{
Siti Soekiswati \\ Universitas Muhammadiyah Surakarta, Indonesia \\ \{soekiswati@gmail.com ${ }^{1}$ \}
}

\begin{abstract}
One indicator of the progress of a country is the degree of the welfare of its citizens. Among the determinants of the protection of the nation is the nation's health status. Indonesia, as a developing country has not been as good as developed countries, so the government enacted BPJS Kesehatan policy since 2014. Existing data shows every year BPJS Kesehatan suffered a loss that is not small, lastly, throughout the year 2016 the number of casualties reached 9 Trillion rupiahs. The writer's observation of the damage is caused by the lack of professional health service model in Puskesmas or private practice by health care practitioners in Indonesian society. Health services that are less professional regardless of the competence that took place since the period of Indonesian Independence until now without much significant change. The authors'research on some students of the faculty of health sciences, health care practitioners and the community of health service users, shows that the condition of health services that are less professional makes each party fell less comfortable, both health care practitioners and the public as consumers. The writer's solution in this regard is Islamic based health education (Q.s. 4: 28, which is by positive law in Indonesia) for students of the faculty of health sciences, health care practitioners and the community of health care users. It is expected to bring up the moral awareness of health personnel to perform professional services according to also understand the competence of each health care practitioners so that they can get optimal function. It is expected to improve the quality of health services, the impact on decreasing loss BPJS Kesehatan so that ultimately can improve the health status of Indonesian society.
\end{abstract}

Keywords: Health Service Competence, Health Law Education, Islamic Base.

\section{Introduction}

BPJS kesehatan had lost up to trillions rupiahs since declared, even in 2016 the number of losses reached 9 trillion due to the very high referral rate to the hospital. Patients could not be handled at Primary Health Centers (PHC) and General Practitioners (GP). The Ministry of Health stated that the surge in referral numbers to the hospital was due to GP's lack of the quality of competence. Then the primary care doctor (PCD) education should be conducted. The analysis received strong opposition from the doctors who realized in the form of peaceful rejection simultaneously in Indonesia on 24 October 2016. The doctor's reason were very 
logical, because a doctor had to pass the competency test so that they could provide primary health services [1].

Public Health Center as a health service institution for the majority of society could not provide professional health services. The study conducted by the author in 2014 stated that the delegation of physician duties authority to paramedics was still a common thing [2].Medical services by paramedics occurred since the early days of PHC (early Indonesian independence), and until now not much change happened. The inconsistency of health law emerged since the rule of health law came into effect, becoming the base of poor primary health services.

The consequence of inconsistency of health law in PHC cause paramedics freely and without feeling guilty to malpractice in their private practice, by providing medical practices that were not their competence. Patient as health service users bear the consequences of under competence services or even out of competence services that provided by the paramedics [3]. The clinician's private doctors often employ paramedics to handle the patients they ought to be responsible for, even this happened in clinics or general practitioners practice as BPJS Health doctors.

Unprofessional health services at the PHC level and some GPs 1 that assigned paramedics to medical services became the main problem in handling the loss of BPJS Health in Indonesia. As a lecturer of candidates for health professionals in the Faculty of Health Sciences and as health practitioners, the author conducted research related to it. There were problems in the realm of health education:

- The lack of knowledge of candidates healthcare professionals about health laws, related to offenses, sanctions, and effects for the health of the patient.

- The ethical education that underpinned the candidate's healthcare professionals in taking the action of health services that prioritized patient safety.

- The lack of knowledge of the community about the health workers competences and their authorities.

\section{Result and discussion}

Research data conducted by the author to 98 students of Physiotherapy of 6th semester obtained almost $80 \%$ of students had not properly understood sanctions related to violations of competence and the impacts for patients. The majority of them (95\%) only understood that the violation of the profession resulted in the disability or death of the patient then subject to legal sanctions. It was not from the early to be told that incompatibility of competence in work was a violation of the law, without having to wait for the consequences.

The ethics lesson delivered was a moral ethics lesson in general, not an Islamic based moral ethic. It resulted that the moral lesson is only limited to science; it was difficult to be expected to raise the conscience of the students as a potential health worker. Awareness of students' conscience was referred to as the education spirit on learning at the level of Higher Education. This spirit of education would affect and impact on applicable practice policies [4].

Optimal health services could only be provided by professional health workers. The lack of education among health professionals was exacerbated by inconsistencies in health law at the PHC level. These were the source of the lack of professional health services at the PHC as well as in the private clinics as GP. Changing inconsistent legal rules required a very long way and many parties involved, as well as dependent on government-run politics.

Law as a means in which contained values or concepts of justice, truth, social benefit and so forth[5][6][7]. Attempts to harmonize the values of relationships that were outlined in the 
values of good and evangelical norms and attitudes as a series of elaborations of the final stages to create peace of life, called law enforcement efforts [8]. Factors affecting law enforcement were the rule of law, law enforcement, law enforcement supporting facilities, the community (the environment in which the law applied) and culture [9]. Based on the above fac, what can be done to seek professional health services was to improve the quality of the health workers education.

Ethics derived from the Greek word "ethos" which meant the character of morality or custom. And in English, "ethics" was good human behavior or actions had to be doneby moral in general. So the meaning of ethics was the science of what could be done or the science of customs [10].

Childress stated that one of the ethical principles in health care was the patients should be treated genuinely by health professionals fairly, properly and equitably (regardless of social strata) [11].

Each profession could be ascertained to have competency standards, as well as health professionals. Mastery of conferencing standards by health workers was very important in health services and was directly related to the quality of health services provided to patients. It was important to improve the understanding and mastery of competency standards for health workers, both in terms of competency standards and their mastery [12].

Competence was a set of intelligent and responsible actions someone had as a condition to be considered capable by the community in performing tasks in a particular field of work. In other words, competence was a combination of skills, personal attributes, and knowledge reflected through work behavior that could be observed, measured and evaluated [12].So that alumni from each education program of health worker had competence which had been tested according to competence standard - professional competence gained through education, training,and apprenticeship over a long and difficult period. The lessons were carefully designed and implemented strictly, then ends with a certification exam (Ministerial Decree Number 045/U/2002 on Higher Education Core Curriculum).

Mastery of competency standards for health personnel became very important because it was directly related to the quality of health services [13].Health services by non-competent health professionals increase Unwanted Events or medical mistakes [12].Related figures of medical mistakes in Malaysia by Ravindran Jegasothy:

"It is impossible to estimate the frequency of medical mistakes, but there can be no doubt that mistakes are much more common than most of us realize. The protection societies have information on the annual rate of claims and complaints, but this represents only a fraction of the total number of accidents. In Malaysia, from our knowledge of complaints that are brought to the attention of the MMA, there are about 20-30 allegations of negligences per year, from millions of patients per year. But there are no public statistics on matters that are referred to the medical defenseorganizations." [14]

The cases of medical mistakes in Indonesia had not been thoroughly researched. As an illustration, in Canada of 2.5 million patients admitted to hospital within one year as many as 185,000 people experienced medical mistakes. Of the 185,000 patients, 70,000 patients (40\%) were actually preventable. In the United States, even medical mistakes showed even higher numbers. The occurrence of medical mistakes in patients causing the death of 44,000 to 98,000 patients per year. This meant that every day there was the death of 120 to 268 patients due to the incorrect doctor's action (Medical Error). It meant that every hour there were five patients died because of medical mistake which was Medical Error type, so it became a national issue in the country. The absence of information about the medical mistake in Indonesia caused the community never to realize the danger of treatment to health workers 
who were lack of competent or even not competent. Prevention of medical mistake could be done with education to the community through counseling that had been the only review about the disease and healthy way of life. Transcendental paradigm education was required not only in prospective personnel or health workers but also in the community of health-care users.

The transcendental paradigm for generating the spirit of healthcare education was chosen to be an alternative solution based on the discovery of neuroscience experts and Harvard anthropologist, Terence Deacon, who discovered SQ (Spiritual Quotient) as a third form of human intelligence. Toward the end of the 1990s Godspot's discovery of a collection of neural networks located in the Temporal lobe of the human brain, which caused human beings to be idealistic and solutive, futuristic, exotic, love, peace, sense of unity, existence and deep beauty. Godspot point was a religious point to be active when people feel the truths of their religion [15]. Spiritual intelligence (SQ) was the ability to give meaning to the worship of every behavior and activity, through the steps and thoughts that were natural (fitrah), to the whole human (hanif), and had the tauhidi idea (integralistic) and principled only because of God [16].God's point on the human brain could be encouraged to instill the spirit of education in college to produce professional health workers.

Based on the notion of transcendental on the Kamus Besar Bahasa Indonesia (KBBI), the ethical education profession-based transcendental Islam was education with a focus to instill a professional ethical perception derived from Islamic teachings. A person performing health services really departed from the right intention, to save lives according to his competence. Cases of patients who are beyond their competence would be referred to a competent health worker, not handled personally for personal economic reasons. Patient safety became the focus of his help, not the economic motive. The basis of his ministry was accountability to God, the Real Judge.

The 58th verse of An Nisa, Al-Qur'an stated that the importance of giving trust to those who were entitled to receive it and that man should be able to decide the law fairly. In line with the hadith of Prophet Muhammad SAW: "When the case is handed over to non-skilled people then wait for its destruction" (Narrated by Bukhary from Abi Hurairah).

Health workers who perform their duties and authorities by their competencies were expected to improve health services more optimally. It also made it easier for the government to adopt policies related to the fulfillment of the needs of health workers in the country. So far, health workers in addition to doctors are forced by the inconsistent legal rules to exercise authority beyond their competence due to a shortage of doctors. The actual state could be read from the statistic ratio of the patient's and physician. Statistics showed that countries with high physician-to-population ratios will always be followed by high levels of health in the country. Indonesia, with the health level occupying the number 90 in the world, had a ratio of doctors per 1000 population of 0.204 . On the other hand, Singapore with a ratio of doctors per 1000 population of 1.95 occupied the level of health number 1 in the world.

Community knowledge of health service facility users was also important to note. The community needs to know the competence of each health worker in the PHC. This knowledge could be given at health counseling by health workers. So it was not only about healthy living but also where people should come if they were sick or just examined themselves as preventive actions from illness. The basis of public education in this issue was Al Ahzab (33): 72 in the Al-Qur'an. The meaning of mandate in verse was the five times prayer, the limbs of man and the treasure. People educated with transcendental paradigm education were expected to be able to choose and attend health workers according to their competence. This was because people had a correct perception of the body that was a mandate that has to be treated properly so that when handled by non-competent would be fatal. The perception that 
endeavors as much as possible for health even though the result was God's business. All endeavors to maintain the health mandate would be accounted for later.

\section{Conclusion}

Less Professional Healthcare at PHC and GP levels cause losses BPJS Health up to 9 trillion in 2016 is a serious problem that had to be addressed. Less professional health services were the cause of the situation. Legal settlement took a long time and a long line, as well as the politics of the ruling government. What could be done was to change the behavior of health workers through health law education with the Islamic transcendental paradigm to health workers and public education of health service users through counseling.

Since the root of the problem was the inconsistency of health law at the PHC level, it was important to immediately review the rule of law related to health service at the PHC level. The cause of the issuance of inconsistency rules was the number of doctors that was far from enough, then providing the required number of the doctor also had to be a serious concern from the government.

\section{References}

[1] S. Darda and N. Senja, Undang-Undang Praktik Kedokteran \& Aplikasinya, 1st ed. Jakarta: Dunia Cerdas, 2013.

[2] S. Soekiswati, "Kebijakan Pelayanan Kesehatan, Studi Pelayanan Pasien Pada Puskesmas Rawat Jalan di Kabupaten Sukoharjo," Universitas Muhammadiyah Surakarta, Surakarta, 2014.

[3] H. Wujoso, "Kejadian (yang) Tak Diinginkan, materi kuliah Etika Profesi Tenaga Medik Magister Ilmu Hukum," Sarjana Universitas Muhammadiyah Surakarta, Surakarta, 2013.

[4] H. Andrianto, "Ruh Pendidikan Tinggi," Kompas, Apr-2013.

[5] Kelik Wardiono; Wafda Vivid Izziyana, "Pekerja Imigran Perempuan dalam Perspektif Islam," Istawa J. Pendidik. Islam, vol. 3, no. 2, pp. 1-24, 2018.

[6] F. I. Febriansyah, "Impact of Ratification of Government Regulations Substituting Law Number 2 of 2017 Becomes Act on Society in Running Activities of Islamic Community Organizations in Indonesia," Al-Hayat J. Islam. Educ., vol. 2, no. 2, pp. 193-201, 2018.

[7] U. Agianto, "Law Enforcement in Indonesia: Exploration of the Concept of Justice in Islamic Dimension with Pancasila Ideology," Al-Hayat J. Islam. Educ., vol. 2, no. 2, pp. 246-254, 2018.

[8] S. Soerjono, Penegakan Hukum. Jakarta: Binacipta, 1983.

[9] S. Soerjono, Faktor-faktor yang Mempengaruhi Penegakan Hukum. Jakarta: Rajawali Press, 1983.

[10] J. W. Bertens, “The Free Encyclopedia.” Utrecht University, 2004.

[11] H. Jonathan, Medical Law. New York: Medical Law, Oxford, 2011.

[12] B. Indra and Suryono, Penyelesaian Sengketa Kesehatan. Jakarta: Penerbit Salemba Medika, 2011.

[13] B. R. Furrow, "Pain Management and Provider Liability: No More Excuses," J. Law, Med. Ethics, vol. 29, no. 1, 2001.

[14] J. Kalra, Medical Errors and Patient Safety. Berlin, New York: DE GRUYTER, 2011. 
[15] Z. Dana and M. Ian, Spiritual Capital: Memberdayakan SQ di Dunia Bisnis. Bandung: PT.Mizan Pustaka, 2005.

[16] G. A. Arya, "ESQ Emotional Spiritual Quotient: Rahasia Sukses Membangun Kecerdasan Emosi dan Spiritual Berdasarkan 6 Rukun Iman dan 5 Rukun Islam," Jakarta: Penerbit Arga, 2001. 